\title{
Recovery assessment of lumber mill wastes: composting product field test
}

\author{
Chang-Tang Chang a,*, Ching-Hwa Lee ${ }^{\mathrm{b}}$, Chyow-Shan Chiou ${ }^{\mathrm{a}}$, \\ $\mathrm{Fu}$-Tien Jeng ${ }^{\mathrm{c}}$

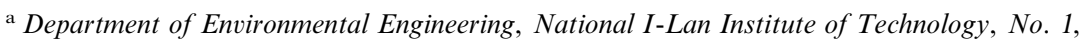 \\ Sheen-Long Road, I-Lan City, Taiwan, ROC \\ ${ }^{\mathrm{b}}$ Department of Environmental Engineering, Da-Yeh University, Chang-Hwa County, Taiwan, ROC \\ ${ }^{\mathrm{c}}$ Graduate Institute of Environmental Engineering, National Taiwan University, Taipei City, Taiwan, \\ $R O C$
}

Accepted 15 August 1998

\begin{abstract}
Lumber mill waste with more than monthly generation of 5000 tons is one of the main solid waste sources in the local I-Lan area. The lumber sawdust together with seafood processing residue and distiller byproducts, is evaluated within a composting machine as a disposal alternative to the conventional landfill and incineration methods. The addition of seabird manure provides adequate $\mathrm{P}$ source for the eventual composting product to be used as an alternative organic fertilizer to conventional chemical fertilizer. Thermophilic bacteria were added to facilitate composting reaction at $70^{\circ} \mathrm{C}$. The composting product was further evaluated for effectiveness as organic fertilizer in greenhouse and field studies. The tested plants include Zinnia elegans, Celosia cristata and Asplenium nidus L. The control experiments include soil alone as well as soil with the addition of chemical fertilizer or compost product. The experimental results demonstrate that flower growth of the C. cristata is enhanced in the presence of composting product. The cost analysis indicates that it is economically feasible to yield a useful composting product. (C) 1999 Elsevier Science B.V. All rights reserved.
\end{abstract}

\footnotetext{
* Corresponding author. Tel.: + 88639 357400/741; fax: + 88639359674 . 
Keywords: Wastes recovery; Sawdust; Composting; Field test; Zinnia elegans; Celosia cristata; Asplenium nidus

\section{Introduction}

Recently, the disposal of solid wastes has presented significant problems in Taiwan. Because of odor and potential hazardous emission as well as land requirement, landfill and incineration alternatives for ultimate solid waste disposal often meet public resistance. As a result, any other alternative for better utilizing solid waste is encouraged. This study is intended to evaluate the feasibility of composting some solid wastes and use the final composting product for agricultural application.

The raw solid material used consists of lumber, seafood processing, and brewery wastes. They are all major industrial byproducts in I-Lan area. For example, sawdust alone accounts for approximately $50 \%$ of the lumber mill waste and amounts more than 1500 tons per month in this area [1]. Although lumber sawdust contains high carbon content, its carbon is difficult to degrade and it lacks of sufficient nutrient either during composting process. As a result, seafood processing residue with its high nitrogen and phosphorus content was added. The monthly production of 2000 ton of this odorous waste, together with 3000 ton/month of the distiller byproducts from local wine manufacturing process has presented major environmental issues locally [2]. Composting the mixture of these three wastes may indeed provide an environmental alternative for waste disposal. It also yields a byproduct useful to local farmers, in terms of improving soil characteristics, addition of $\mathrm{N}$ and $\mathrm{P}$ nutrient, and eliminating costly chemical fertilizer.

The present study differs with those of previous composting study $[3,4]$ in several aspects. First, one of the material used, sawdust is hardly employed before because of its cellulose content. Second, the composting equipment employed is of a machine type with a heat controller to maintain the thermophilic temperature at $70^{\circ} \mathrm{C}$ to shorten the composting time to only 4-5 days, and to eliminate the odor

Table 1

The element waste compositions of raw materials and compost

\begin{tabular}{lrlllll}
\hline Species & \multicolumn{7}{l}{ Compositions } & & & \\
\cline { 2 - 7 } & Moisture (\%) & $\mathrm{pH}$ & $\begin{array}{l}\text { Organic } \\
\text { contents (\%) }\end{array}$ & $\mathrm{N}(\%)$ & $\mathrm{P}(\%)$ & $\mathrm{K}(\%)$ \\
\hline Sawdust & $27.0 \pm 8.5$ & $6.5 \pm 0.5$ & $86.6 \pm 5.3$ & $0.3 \pm 0.2$ & $0.5 \pm 0.5$ & $0.6 \pm 0.5$ \\
Brewery bregs & $84.2 \pm 4.3$ & $3.8 \pm 1.0$ & $88.0 \pm 9.1$ & $0.5 \pm 0.2$ & $0.1 \pm 0.1$ & $0.1 \pm 0.1$ \\
Rice brans & $8.8 \pm 2.4$ & $6.3 \pm 0.4$ & $80.6 \pm 6.3$ & $0.9 \pm 0.3$ & $0.3 \pm 0.1$ & $1.1 \pm 1.0$ \\
Shrimp shells & $7.1 \pm 3.6$ & $7.5 \pm 0.5$ & $71.9 \pm 3.4$ & $5.9 \pm 2.1$ & $7.1 \pm 2.3$ & $1.0 \pm 0.5$ \\
Seabird manure & $6.9 \pm 2.7$ & $7.3 \pm 0.5$ & $17.9 \pm 2.3$ & $1.5 \pm 0.5$ & $15.1 \pm 8.2$ & $1.5 \pm 1.0$ \\
Compost & $32.0 \pm 5.0$ & $7.0 \pm 0.5$ & $85.0 \pm 10.0$ & $5.0 \pm 1.0$ & $3.0 \pm 1.0$ & $1.0 \pm 0.5$ \\
\hline
\end{tabular}



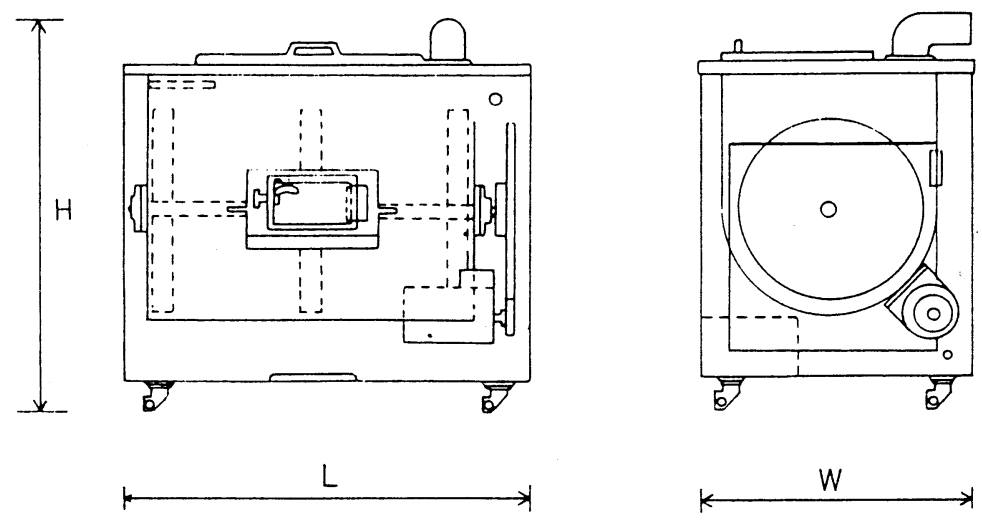

Fig. 1. The diagram of high speed compost production machine.

Table 2

Field test parameters in greenhouse and field

\begin{tabular}{|c|c|c|c|}
\hline \multirow[t]{2}{*}{ Case } & \multicolumn{3}{|l|}{ Plant } \\
\hline & A. nidius & Z. elegans & C. cristata \\
\hline \multirow{4}{*}{$\begin{array}{l}\text { Treatment } \\
\text { condition }\end{array}$} & 1. Soil only & 1. Soil only & 1. Soil only \\
\hline & 2. Soil and organic fertilizer & $\begin{array}{l}\text { 2. Soil and organic } \\
\text { fertilizer }\end{array}$ & $\begin{array}{l}\text { 2. Soil and organic } \\
\text { fertilizer }\end{array}$ \\
\hline & 3. Soil and chemical fertilizer & $\begin{array}{l}\text { 3. Soil and chemical } \\
\text { fertilizer }\end{array}$ & $\begin{array}{l}\text { 3. Soil and chemical } \\
\text { fertilizer }\end{array}$ \\
\hline & $\begin{array}{l}\text { 4. Media and organic fertilizer } \\
\text { 5. Media, organic and chemical } \\
\text { fertilizer }\end{array}$ & & \\
\hline Places & Greenhouse & Farm & Farm \\
\hline Period & 4 months & 3 months & 3 months \\
\hline
\end{tabular}

problems. The effectiveness of final composing product as a fertilizer is further evaluated in the greenhouse and field studies by growing two types of flowers, Zinnia elegans and Celosia cristata, and plant Asplenium nidus L. Lastly, a benefit/ cost analysis is provided to assess the economic feasibility of using this composting process.

\section{Material and methods}

\subsection{Materials}

The main compositions of the raw materials include lumber sawdust brewery, bergs, and seafood wastes. The seabird excrement with its high P content $(15 \%)$ was 
also added to increase the $\mathrm{P}$ concentration in the compost. Rice brans were also used as a bulking agent. The thermophilic bacteria (strain BS), obtained from the Taiwan Bacterial Research Center, were added in the composting material. The nutrient and organic content of these wastes are shown in Table 1. A high efficiency machine (made by Leading, model BM-120S) was used as a composting vessel (Fig. 1). It can adequately control temperature (with an electric heat controller), air flow rate, mixing time, and rotation speed. The maximum capacity is about $100 \mathrm{~kg}$ (wet weight).

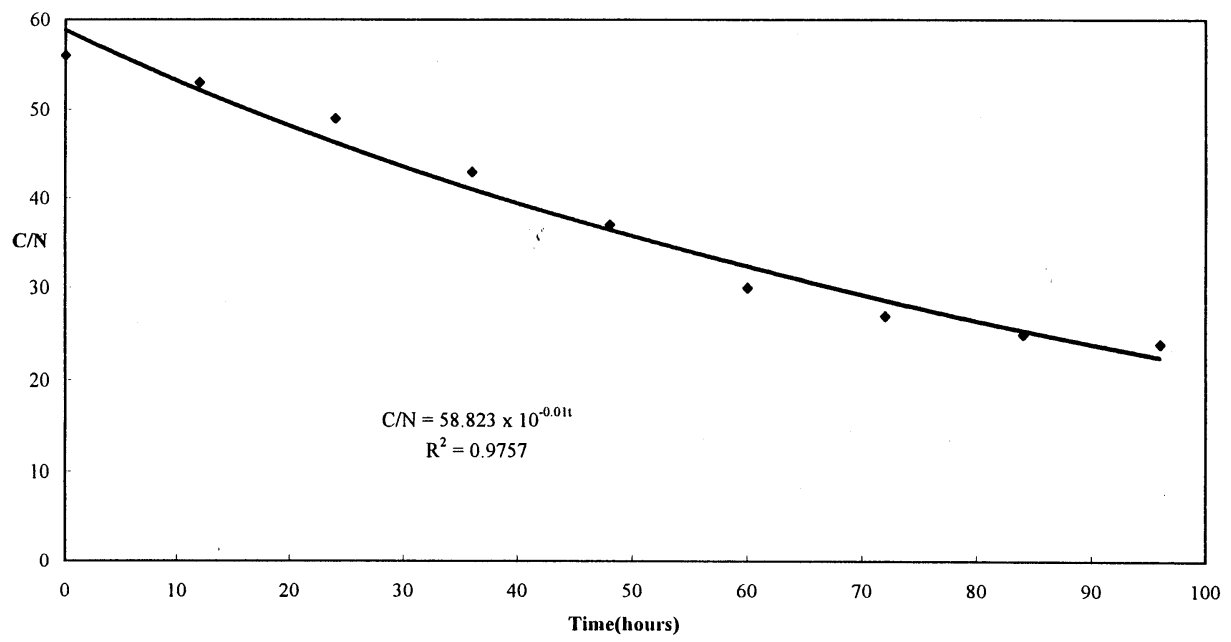

Fig. 2. The $\mathrm{C} / \mathrm{N}$ decreasing tendency of complex compost.

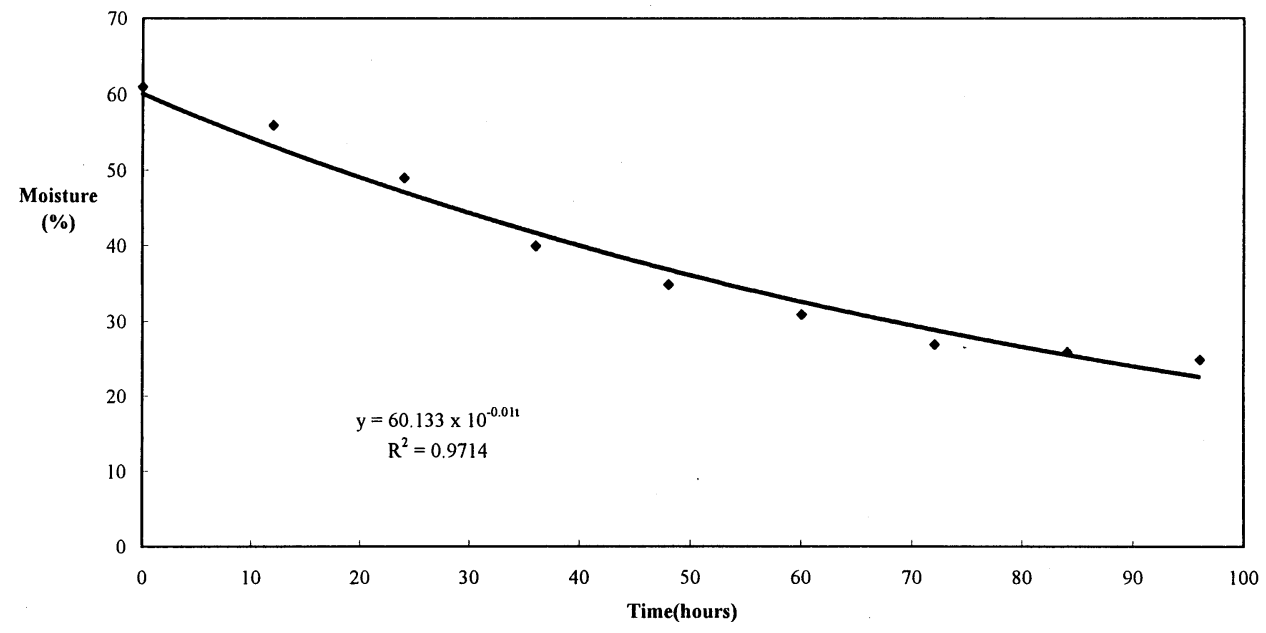

Fig. 3. The moisture decreasing tendency of complex compost. 


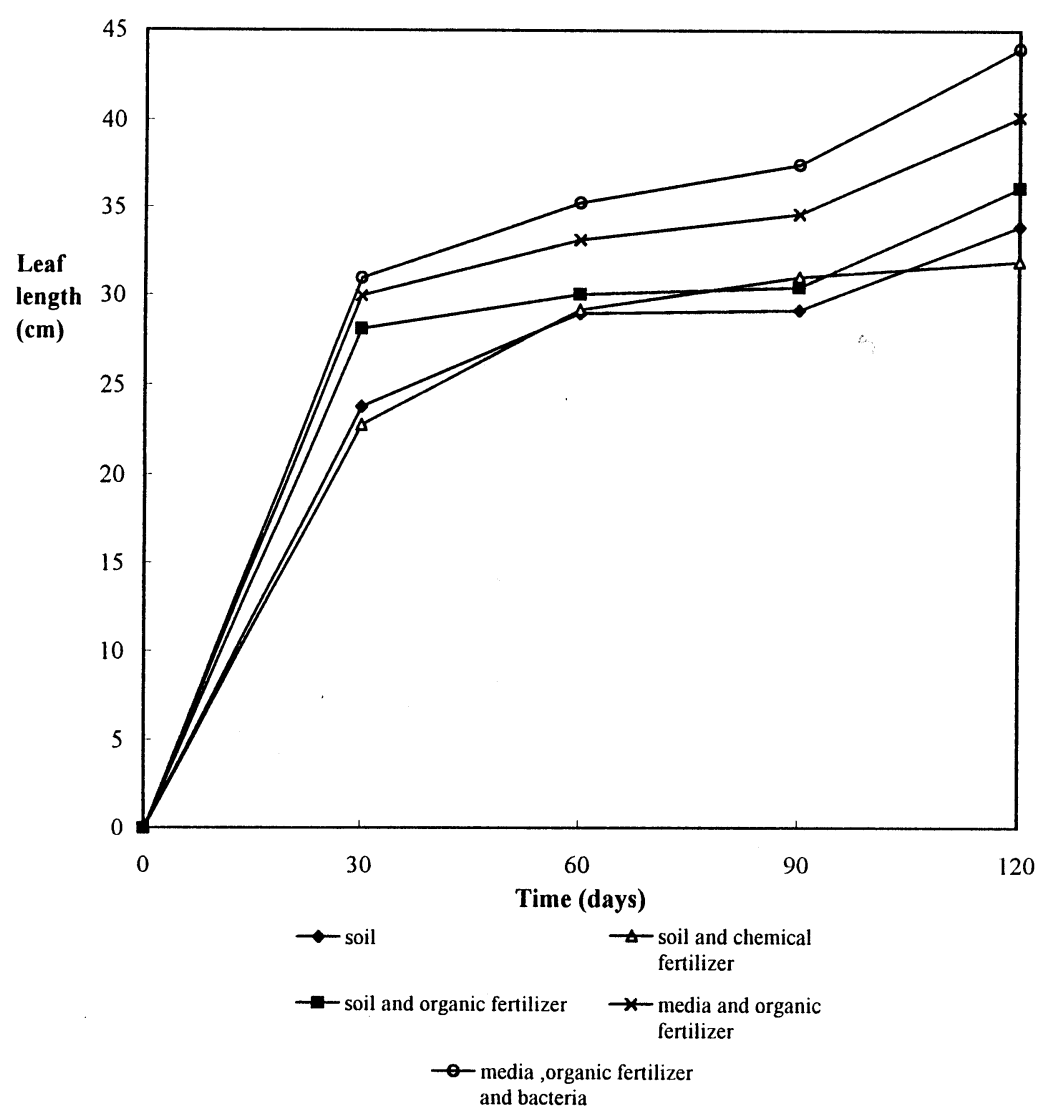

Fig. 4. The leaf length enlonging tendency of $A$. nidus.

\subsection{Composing experiments}

Approximately $100 \mathrm{~kg}$ of the mixture waste $(25 \mathrm{~kg}$ sawdust, $35 \mathrm{~kg}$ brewery bregs, $10 \mathrm{~kg}$ seafood waste, $20 \mathrm{~kg}$ seabird excrement, and $10 \mathrm{~kg}$ rice brans), together with approximately $100 \mathrm{~g}$ bacterial strain BS mixed with fine rice brans was added into the machine. The water was initially added to maintain the initial moisture content of approximately $55-60 \%$. The temperature and air flow rate were controlled at $70^{\circ} \mathrm{C}$ and $0.1 \mathrm{~m}^{3} / \mathrm{m}^{3}$ per min (compost volume/air flow rate), respectively. The mixing duration was controlled for $20 \mathrm{~min}$ on with $5 \mathrm{~min}$ off; mixing rotation direction was then switched at the next sequence by an electrical switch. The composting process was terminated after about 5 days, and the analysis of $\mathrm{C} / \mathrm{N}$, moisture, and soybean germination efficiency were determined.

The fine rice brans and bentonite were added to the final composting product in a machine to yield granular fertilizer-like materials to be used in subsequent field and greenhouse studies. 


\subsection{Field test}

In the current study, both greenhouse and field experiments were used to assess the effectiveness of composting product. The type of different materials applied is summarized in Table 2. There are five different treatments in greenhouse study: soil alone; soil with chemical fertilizer; soil with composting product; additive medium with composting product; and soil with composting product and bacteria (Dade No. 18). The chemical fertilizer used was the Taifai Complex No. 43. For comparison, additional medium consisting of dead algae, peat and fern chips with bacteria as treatment 5 in Table 2 was used. The $\mathrm{N}$ and $\mathrm{P}$ contents of the soil used were $1 \%$ and $0.1 \%$, respectively.

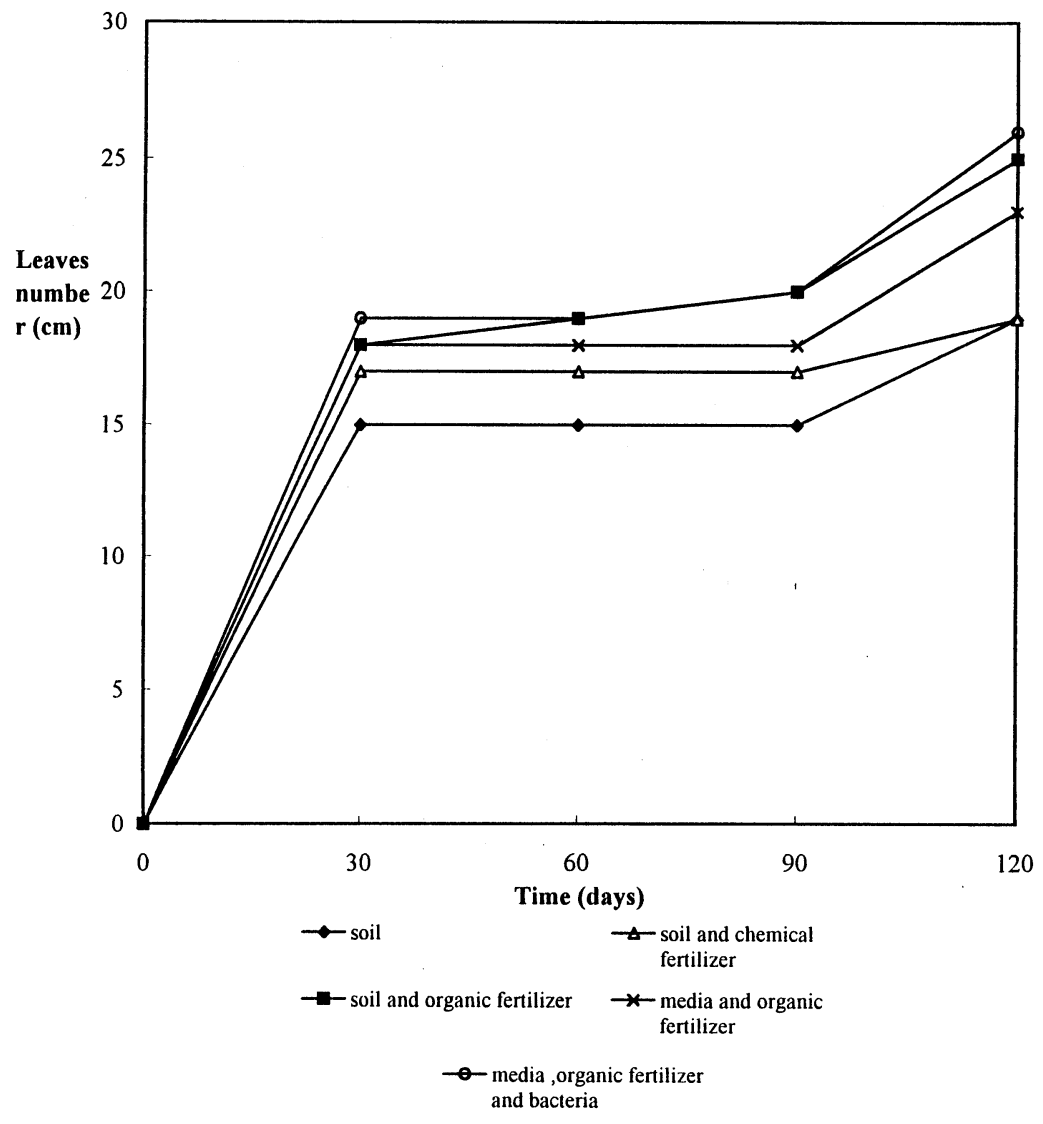

Fig. 5. The leaves number increasing tendency of $A$. nidus. 


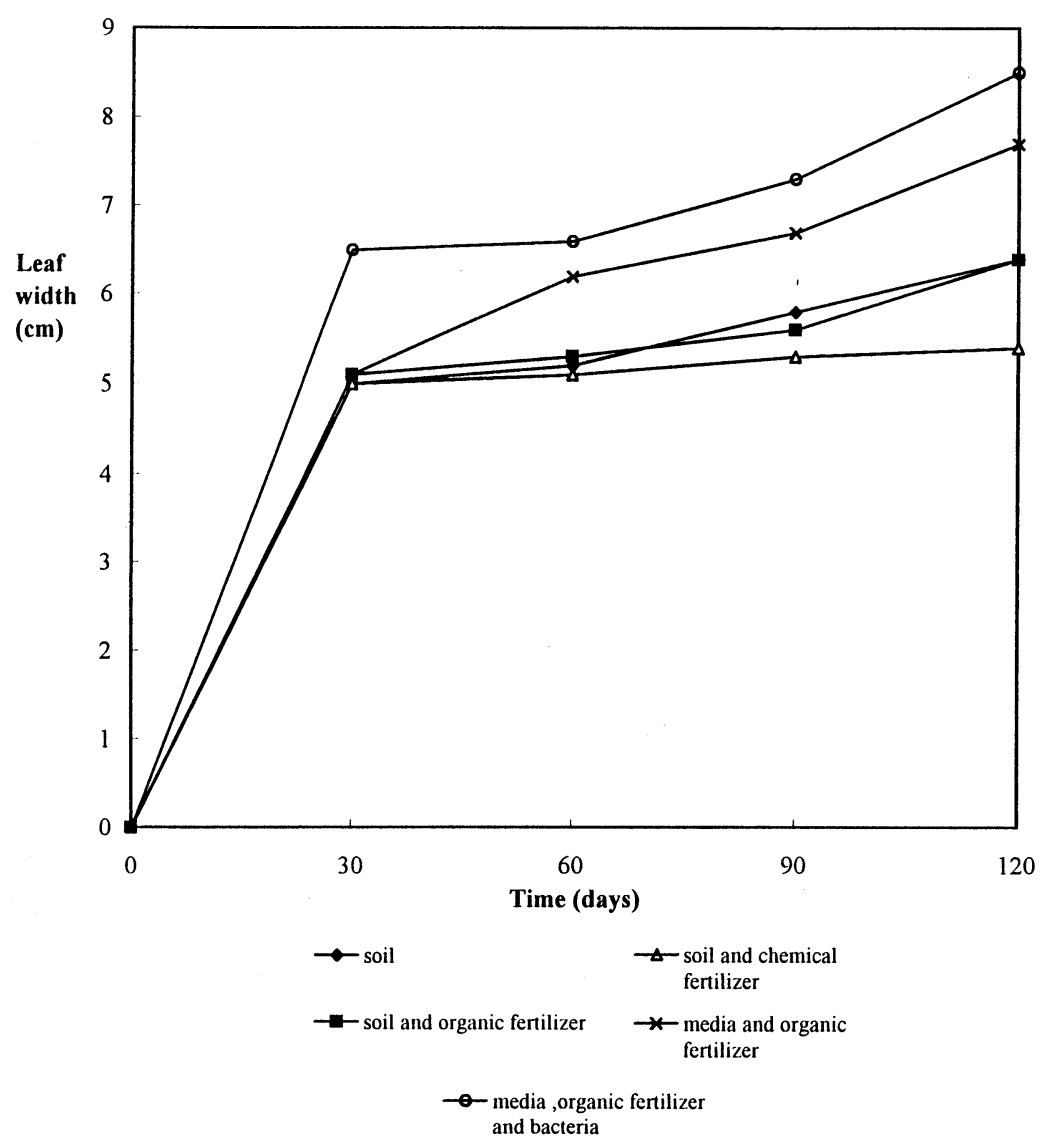

Fig. 6. The leaf width widening tendency of $A$. nidus.

The A. nidus was planted in $25010-\mathrm{cm}$ height pots (volume: $430 \mathrm{ml}$ ). Each of the five different conditions (Table 2) were applied to 50 pots. The $Z$. elegans and $C$. cristata were planted in a total of 18 plots with three different conditions (Table 2). Each plot covers an area of $10 \mathrm{~m}$ by $2 \mathrm{~m}$. The amount of fertilizing material added were about $2 \mathrm{~kg}\left(100 \mathrm{~g} / \mathrm{m}^{2}\right)$ for each plot in the field, and $2 \mathrm{~g}$ for each pot in the greenhouse. In general, these materials were added on the top of soil after 2 weeks planing. The experiment lasted about 4 months for $A$. nidus, and 3 months for $Z$. elegans and C. cristata.

The length, number, and width of leaves as well as the flower diameter were measured every half month. Ten randomly selected pots in each condition were used to record the above parameters; the average value of at least half of the total measurements was reported. After harvesting, the root of some plants were visually inspected to observe any effect of root structure with these different treatments. 


\subsection{Analysis}

The $F$-test and the variance statistical analysis [5] were used. The interior parameters included length, width, and numbers of leaves as well as flower size, and the exterior parameters were three treatments of soil alone, soil with chemical fertilizers, and soil with composting product. The confidence level used in the $F$-test was $95 \%$.

A cost analysis was performed to evaluate the economic feasibility of using composing product. It adds additional cost to transform the original composting form into granular form. The economic assessment essentially covers costs for waste reduction, construction, operation and maintenance.

The N, P and $\mathrm{K}$ contents of different materials were analyzed according to the standard methods described in the manual published by the Environmental Protection Administration in Taiwan [6]. The moisture and organic contents were measured by monitoring the weight of samples at 103 and $550^{\circ} \mathrm{C}$ [7].

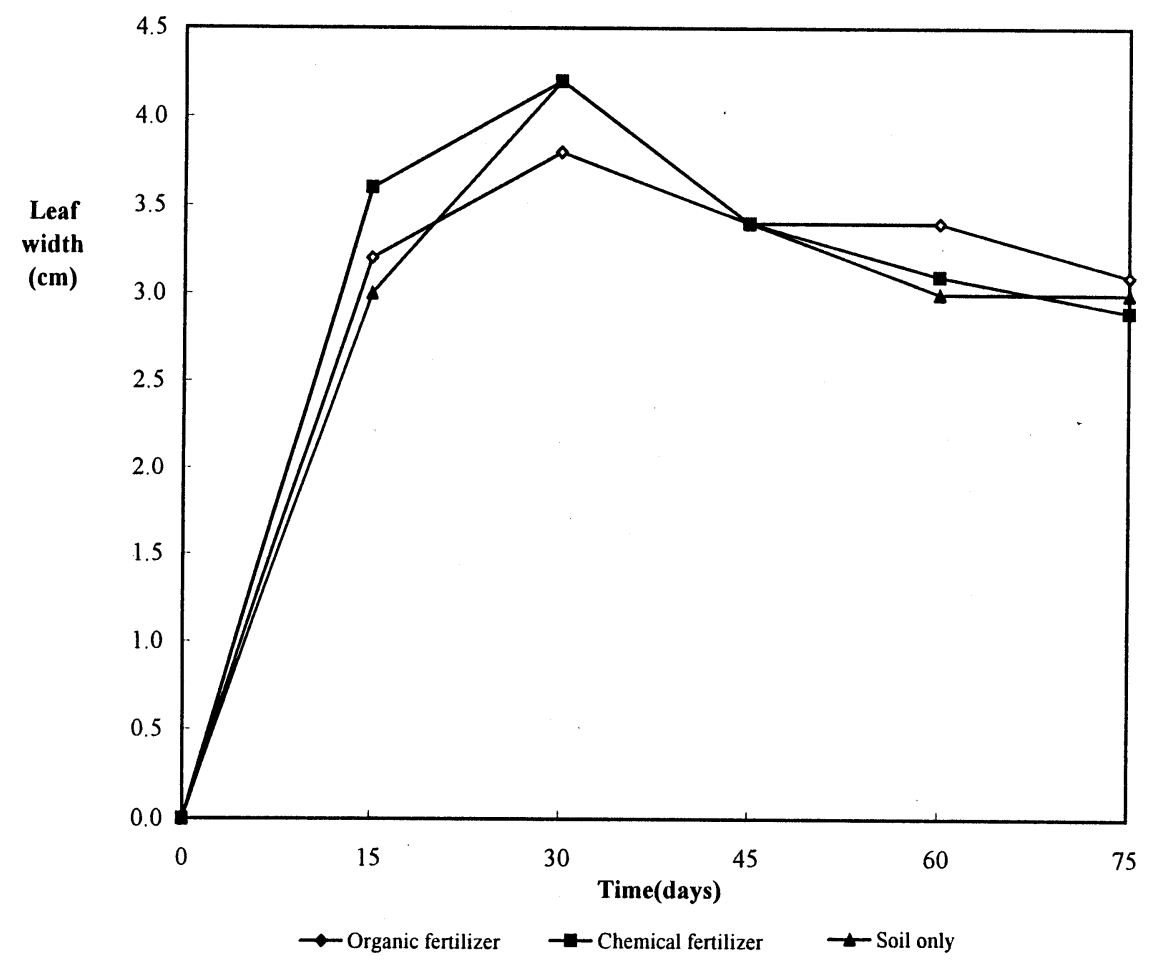

Fig. 7. The leaf widening tendency of $Z$. elegans. 


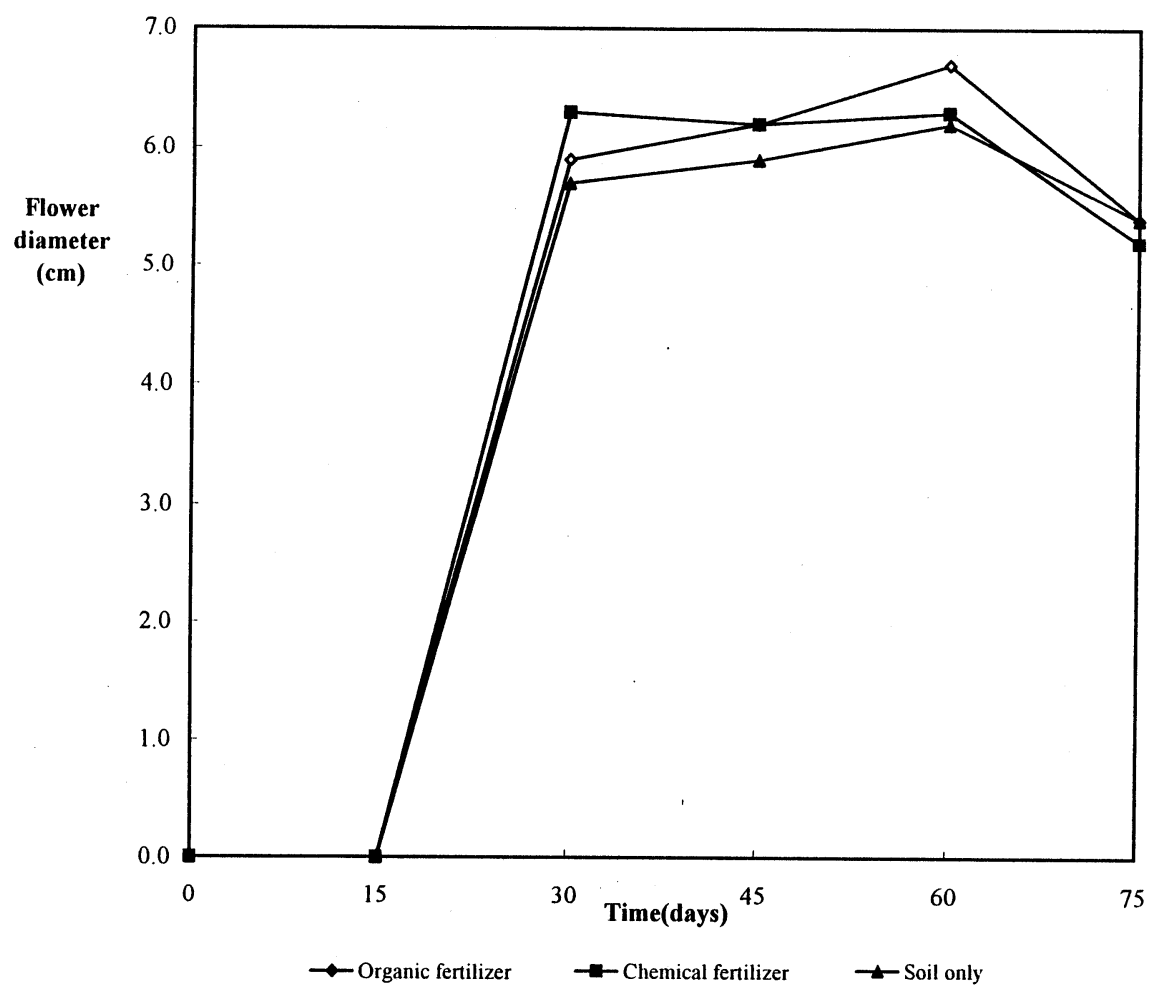

Fig. 8. The flower diameter enlarging tendency of Z. elegans.

\section{Results}

\subsection{Composting}

Based on information from Table 1, the ratio of sawdust, brewery bregs, rice brans, shrimp cells, and additives was calculated to be $5: 7: 2: 2: 4$ to obtain approximately N:P:K ratio of 5:3:1 in the final composing product. This ratio was initially used to add the necessary amount of each raw material for final $100 \mathrm{~kg}$ waste.

The plots of moisture and $\mathrm{C} / \mathrm{N}$ contents of one particular composting condition with composting time are shown in Figs. 2 and 3. The $\mathrm{C} / \mathrm{N}$ content decreased from the original $55 \%$, to $25 \%$ after 4 days. Furthermore, the relationship between $\mathrm{C} / \mathrm{N}$ and time $(t)$ is shown as Eq. 1.

$$
\mathrm{C} / \mathrm{N}=58.82 \times 10^{-0.01 t}
$$

The organic carbon disappearance is due to its biotransformation into carbon dioxide. The moisture loss is due to water evaporation from heating, as generated from in-situ microbial reaction and electrical heat, and from escaping air. Whereas, the relationship between moisture $(y)$ and time $(t)$ is shown as Eq. 2. 


$$
y=60.13 \times 10^{-0.01 t}
$$

The soybean germination of final composting product was well about $90 \%$. The compost was added with fine rice brans to further decrease the moisture to $12 \%$ before making granular product in a separate machine. Although not measured, it is believed that pathogens present in raw materials are eliminated, since few can survive under such harsh conditions of $70^{\circ} \mathrm{C}$ and 4 days.

\subsection{Field test}

The growth results of $A$. nidus are shown in Figs. 4-6, clearly indicating that the growth rate of the leaves with composting product outpaced those of soil alone and soil with chemical fertilizer. The results (not shown) also indicate that some leaves with chemical fertilizer treatment were damaged after 120 days. The electronic conductivity $(\mathrm{EC})$ and $\mathrm{pH}$ (soil:water ratio $=1: 10$ ) of the soil after 120 days in soil alone treatment were $580 \mathrm{mhos} / \mathrm{cm}$ and 6.7 , respectively. For comparison, the values of EC for the soil with composting byproduct was $430 \mu \mathrm{mhos} / \mathrm{cm}$, and for chemical fertilizer $2370 \mu \mathrm{mhos} / \mathrm{cm}$; the corresponding $\mathrm{pH}$ were 7.15 and 5.49 . The stable $\mathrm{pH}$ condition for the soil with composting product may be partially respon-

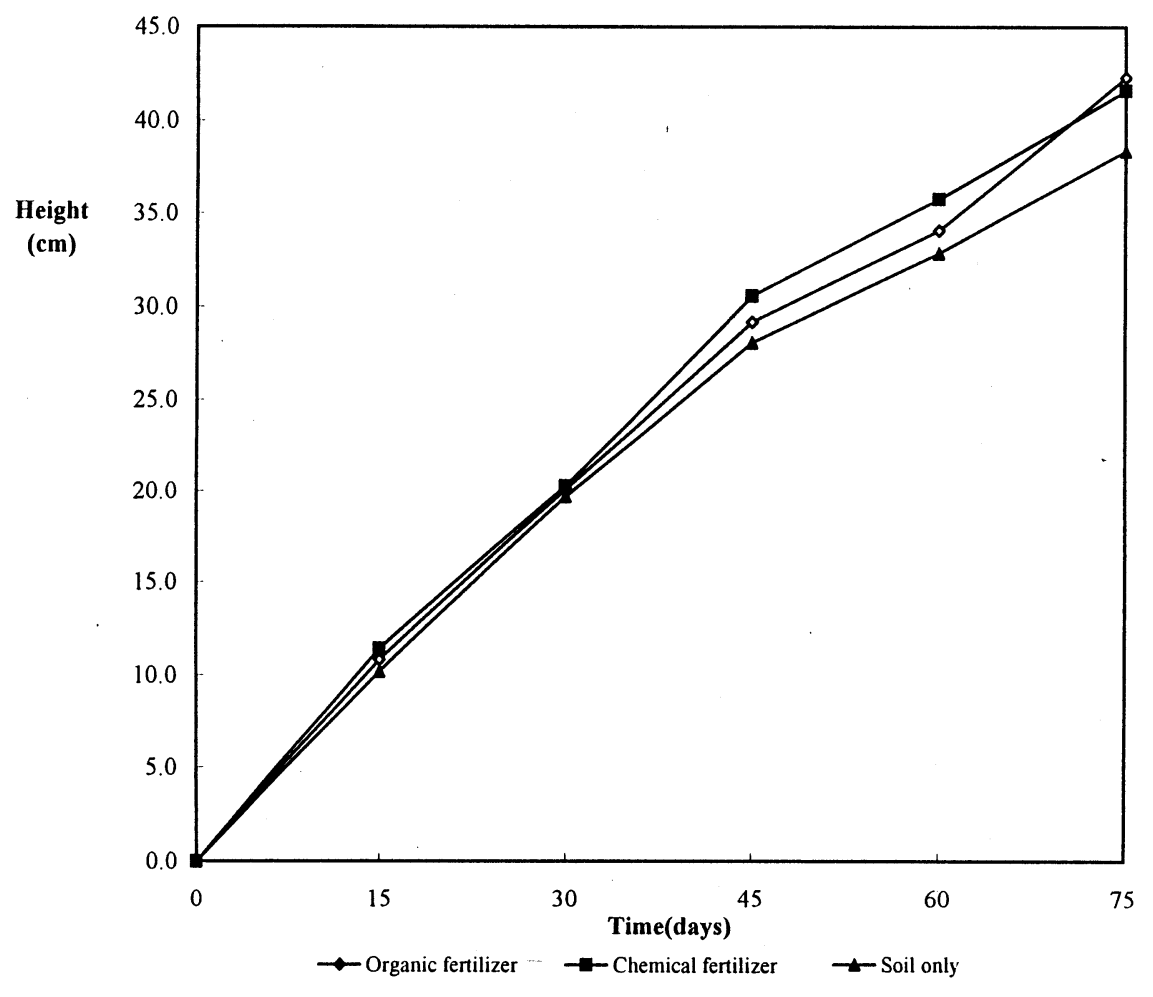

Fig. 9. The plant height enlonging tendency of Z. elegans. 


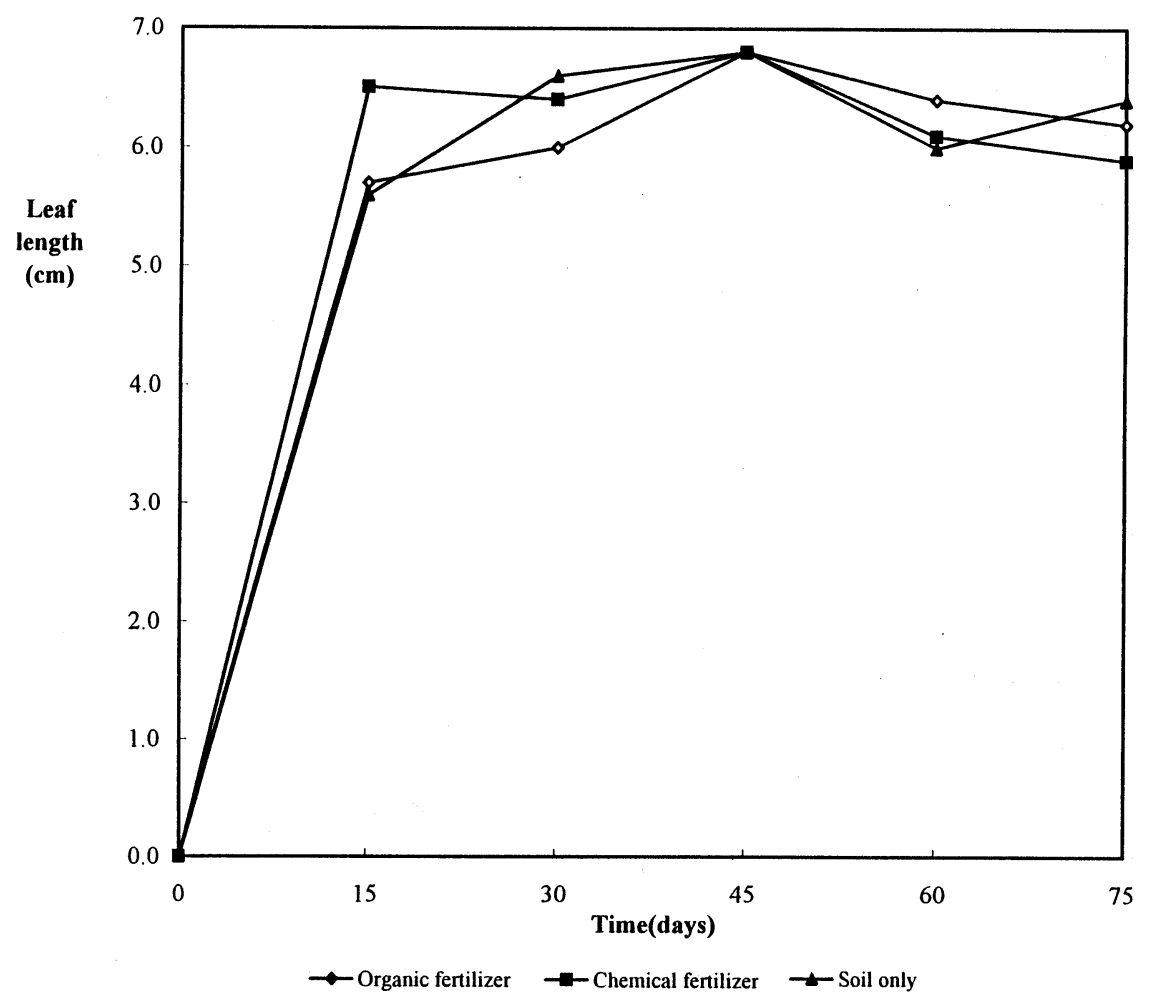

Fig. 10. The leaf length enlonging tendency of $Z$. elegans.

sible for better growth. It appears that the use of compost is indeed a better alternative to the conventional chemical fertilizer.

The field was planted with $Z$. elegans and $C$. cristata in soil alone, and with two types of treatments. Essentially, all three treatment yield the similar flower size and height (Figs. 7-10) for Z. elegans. However, at the end of growth, the leaves were somehow damaged by chemical fertilizer, shown in Figs. 8 and 13 . The leaves growth patterns of $C$. cristata (Figs. 11-14) are slightly different than those of $Z$. elegans. It appears that the treatment with chemical fertilizer yields a better leaf growth than those with compost or soil alone. However, their effect on the flower size is indistinct and relative to fertilizer.

\subsection{Statistical analysis}

This analysis determines whether the statistical differences are significant among the three treatment in the field test. Tables 3 and 4 presents the summary ANOVA statistics for Z. elegans and C. cristata, respectively. Obviously, the three groups of random samples may not represent all possible experimental conditions. Nevertheless, the data of plant growth show only a slight difference among the three 
treatments, based on two degrees of freedom. The critical value of $F$ is 9.6, as computed by the harmonic interpolation with the confidence level 95\% [6]. Only the $F$-values of 19.4 for the $C$. cristata flower diameter is above the critical value. This finding suggests that the fertilizers heavily influence the growth of $C$. cristata flowers.

\subsection{Economic analysis}

Economic analysis comprises of assessing the benefit and cost of lumber mill composting. The cost analysis is based on composting capacity of 7200 ton/year, $80 \%$ operation capacity and total operation of 300 days/year. The capacity is designed based on the specification of composting machine, and to some extent land availability. The quantity of annual materials reduced is: sawdust, 3.7 kton; brewery brags, $5.1 \mathrm{kton}$; and additive agent (seafood waste and seabird excrement) 2.9 kton. Based on the specific gravity (0.8) of composting product, the volume of granular compost is approximately $18300 \mathrm{~m}^{3} /$ year.

The capital cost (engineering, plant, composting machine, control equipment, planning, and management) is about 2.84 million US dollars, based on the unit cost

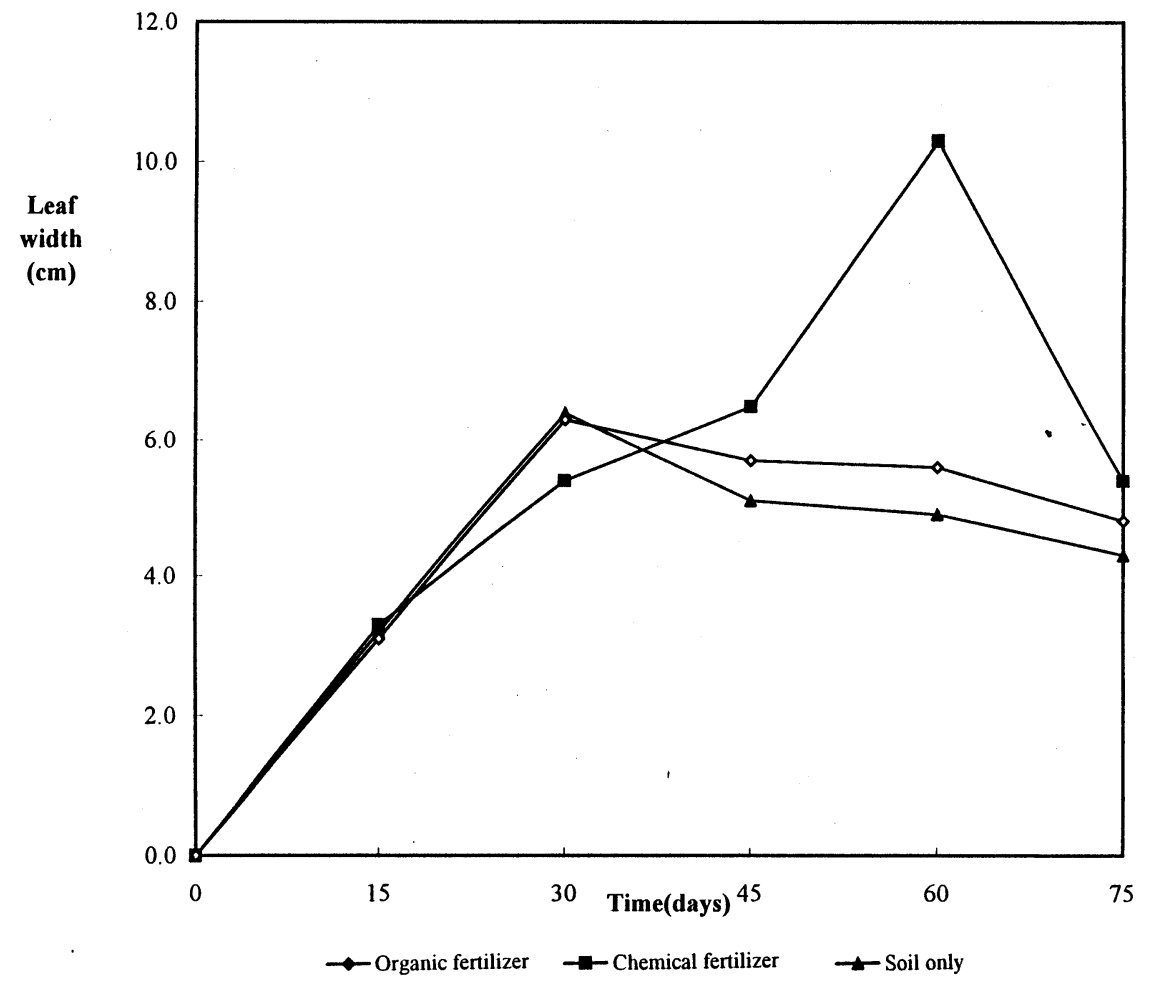

Fig. 11. The leaf widening tendency of C. cristata. 


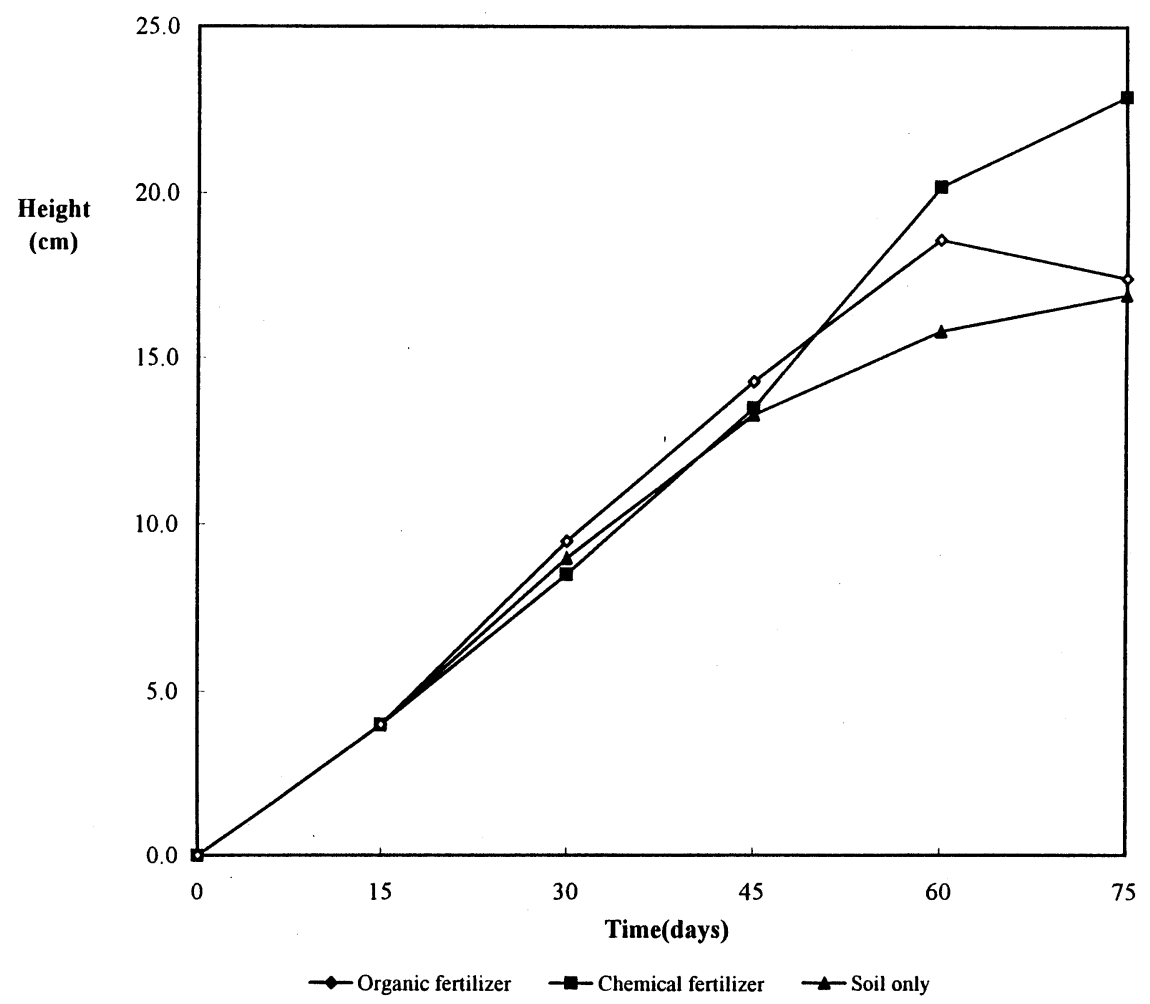

Fig. 12. The plant height enlonging tendency of C. cristata.

shown in Table 5. The costly dryer and granular-making machine are added to make granular composting product. The annual operation and maintenance cost is approximately a half million dollars (Table 6). Energy cost alone amounts to approximately $30 \%$ of the overall cost. The benefit and cost analysis including analysis of transportation costs indicates a slight advantage in using composting product (Table 7). The product market value is based on $\$ 1200 /$ ton. For comparison, the current price for chemical fertilizer is $\$ 1300 /$ ton.

\section{Discussion}

The objective of composting wastes is to reduce quantity, dissemination of pathogens, decrease germination of weeds, and to destroy evil-smelling compounds. Further, the purpose of composting is to produce a compost valuable for farmers and gardeners to be used instead of chemical fertilizers and for protection of the soil structure. During compostation, all the soluble nitrogen compounds and the proteins are decomposed. Typically half the nitrogen is transformed to ammonia and lost by volatilization [4]. The remaining nitrogen is used by the microbes to 
build up microbial proteins, often called biomass. In the soil, the biomass must be mineralized by other living organisms, before the nitrogen becomes available to plants. The results show that not until about 2 weeks after incoporation into the soil the nitrogen in biomass slowly becomes available. Most of the moisture was lost because of evaporation from heating, as generated from digested biological heat and electric heat.

The field study supplies the effectiveness of fertilizers. Notably, the Z. elegans brought up with organic fertilizers, media, and bacteria has the best growth patterns. This finding suggests that the fertilizer, bacteria, and media are prerequisite to bring up the plants well. The results also show that the growth rate with adding chemical fertilizers are the worst in the final stage. The leaves were harmed by chemical agents and became smaller. Additionally, the flower diameter makes no difference between chemical fertilizer and organic fertilizer. Herewith, the organic composts can replace chemical agents to bring up Z. elegans because the production rate with organic composts is almost the same as chemical fertilizer. It is benefit to use the resource organic fertilizer since the chemical fertilizers are not cheap in Taiwan.

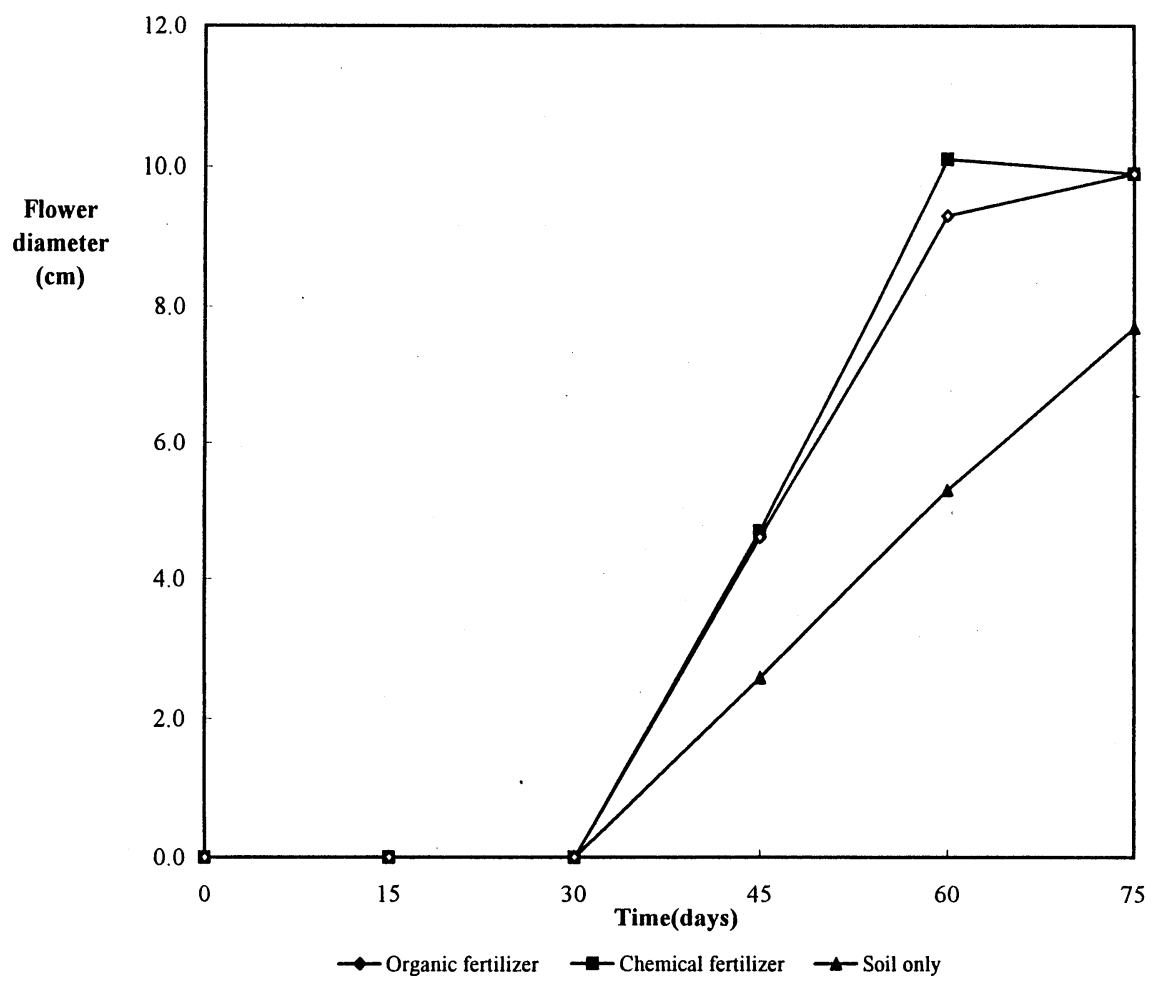

Fig. 13. The flower diameter enlarging tendency of C. cristata. 


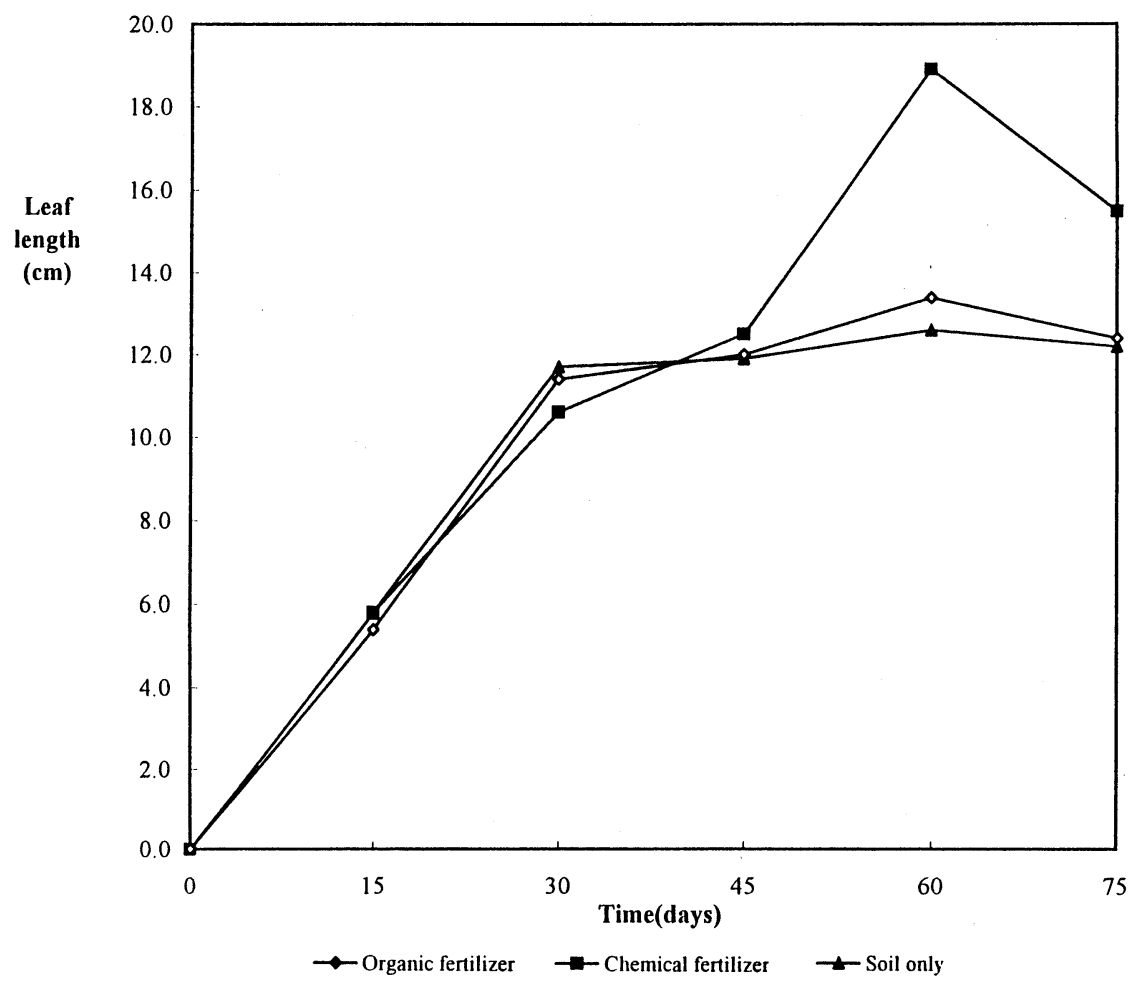

Fig. 14. The leaf enlonging tendency of C. cristata.

The data of plant growth rate show a slight difference between $Z$. elegans and $C$. cristata. C. cristata flower diameter growth rate makes no difference between organic compost and chemical agents; but the leaves width depends on the fertilizer. After statistical analyzing, at least one statistically significant difference exists among the treatment groups. The difference is caused from the leaves of $C$. cristata are smaller and easily influenced by fertilizers. In addition, the $\mathrm{N}$ contents is obviously the most important nutrient. It is consistent with the plant leaves and flower are influenced by $\mathrm{N}$ contents primarily.

The cost of producing complex organic fertilizers is higher than the agents since they require more machine and techniques to produce fertilizers. Furthermore, the dryers and granular-making machines are necessary to make granular compost. The manufacturing processes of granular fertilizer are more complicated and much labor is used to make fertilizers. However, the total reduction quantity of making granular organic fertilizer is larger than the others because the fertilizers are drier and can be easily lost in a ganular-making machine. Further, the price of granular organic fertilizer is more expensive than the others. It is also more convenient for using granular complex fertilizers. In brief, it benefits to produce granular organic fertilizer. 
Table 3

The ANOVA table of $Z$. elegans

\begin{tabular}{lllccl}
\hline Parts of plant & Parameters & df & SS & MS & $F^{\mathrm{a}}$ \\
\hline Flower diameter & Treat & 2 & 6.31 & 3.2 & - \\
& Error & 3 & 2.73 & 0.9 & 3.52 \\
& Total & 5 & 9.04 & - & - \\
Height & Treat & 2 & 91.47 & 45.74 & - \\
& Error & 3 & 244.74 & 81.58 & 0.56 \\
Leaf width & Total & 5 & 336.21 & - & - \\
& Treat & 2 & 1.00 & 0.5 & - \\
& Error & 3 & 0.61 & 0.2 & 2.5 \\
Leaf length & Total & 5 & 1.61 & - & - \\
& Treat & 2 & 14.32 & 7.16 & - \\
& Error & 3 & 11.89 & 3.96 & - \\
\hline
\end{tabular}

a The growth of Z. elegans depends on fertilizer slightly since the $F$-value is below 9.6.

\section{Conclusions}

The objectives of composting wastes are to reduce waste quantity, elimination of pathogens, and destruction of odor-causing substances. Further, the final composting product can provide farmers and gardeners with a better alternative to chemical fertilizers. These goals of waste minimization and resource recovery are achieved in the present study.

Table 4

The ANOVA table of $C$. cristata

\begin{tabular}{llllll}
\hline Parts of plant & Parameters & df & SS & MS & $F$ \\
\hline Flower diameter & Treat & 2 & 0.31 & 0.16 & - \\
& Error & 3 & 0.03 & 0.008 & $19.4^{\text {a }}$ \\
& Total & 5 & 0.34 & - & - \\
Height & Treat & 2 & 17.44 & 8.72 & - \\
& Error & 3 & 35.35 & 11.78 & 0.7 \\
Leaf width & Total & 5 & 52.79 & - & - \\
& Treat & 2 & 0.07 & 0.033 & - \\
Eeaf length & Error & 3 & 0.02 & 0.008 & - \\
& Total & 5 & 0.09 & - & - \\
& Treat & 2 & 0.05 & 0.03 & - \\
\hline
\end{tabular}

a The growth of $C$. cristata depends on fertilizer since the $F$-value can be above 9.6 . 
Table 5

The construction cost of the soil improving plant

\begin{tabular}{llrlr}
\hline Item & Unit & Cost & Amount & $\begin{array}{l}\text { Total cost (unit: US dollars } \\
\text { (in thousands) }\end{array}$ \\
& & & & 200 \\
Civil engineering & $10^{3} \mathrm{~m}^{2}$ & 30.4 & 6.6 & 800 \\
Plant frame & $10^{3} \mathrm{~m}^{2}$ & 242.4 & 3.3 & 120 \\
Storage tank & Set & 40 & 4 & 600 \\
Manufacturing machine & Set & 600 & 1 & 20 \\
Second digestion area & Set & 20 & 1 & 40 \\
Aeration system & Type & 40 & 1 & 40 \\
Transport system & Type & 40 & 1 & 20 \\
Bagging machine & Piece & 20 & 1 & 120 \\
Air pollution treatment equipment: (1) & Set & 120 & 1 & \\
$\quad$ scrubber; (2) biological filtration bed & & & & 80 \\
Monitor sysem & Type & 80 & 1 & 40 \\
Pipe system & Type & 40 & 1 & 120 \\
Collection system & Type & 120 & 1 & 60 \\
Planning cost & Case & 60 & 1 & 60 \\
Techniques cost & Case & 60 & 1 & 80 \\
Mangement cost & Case & 80 & 1 & 320 \\
Dryer & Set & 320 & 1 & 80 \\
Granular-making machine & Set & 80 & 1 & 2840 \\
Total & & & & \\
& & & &
\end{tabular}

In the present study, the otherwise landfill- or incinerating-disposal solid wastes were used instead as raw materials for composting. Specifically the otherwise wasted lumber sawdust is able to produce a good composting product. Both greenhouse and field studies, using C. cristata, Z. elegans and A. nidus L., clearly indicate the superiority of composting product over the conventional chemical fertilizer. The cost effective analysis further provides that the composting process is economically feasible.

Table 6

The operation and maintenance cost of soil improving agent

\begin{tabular}{llccc}
\hline Item & Unit & Cost & Amount & $\begin{array}{l}\text { Total cost (unit: US dollars } \\
\text { (in thousands)/year) }\end{array}$ \\
\hline Man-hour & Person-year & 28 & 8 & 224 \\
Maintenance & Mouth & 40 & 3 & 120 \\
Power & $10^{3}$ kwh & 0.08 & 800 & 164 \\
Management & Case & 112 & 1 & 112 \\
Miscellaneous & Set & 40 & 1 & 40 \\
Total & & & 560 \\
\hline
\end{tabular}


Table 7

The benefit and cost of the three products

\begin{tabular}{llr}
\hline Item & Type of cost & Granular fertilizer (unit: US dollars/ton) \\
\hline Income & 1. Selling cost & 1200 \\
& 2. Brewery bregs treatment cost & 164 \\
Outcome & 1. O and M cost & 560 \\
& 2. Interest & 100 \\
& 3. Sawdust transport cost & 68 \\
& 4. Products transport cost & 144 \\
& 5. Brewery brags transport cost & 80 \\
& 6. Bacteria & 16 \\
& 7. Nutrient & 280 \\
Benefit/cost & (Income - outcome)/outcome & 11.8 \\
\hline
\end{tabular}

\section{References}

[1] Wu JL. Study on the Cases of Sludge Reuses and Resources in Taiwan. Taiwan: Sludge Reuses and Resources Technology, Industrial Development and Affairs Bureau, 1993.

[2] Chang CT. Assessment of the Wood Processing Wastes Resources and Treatment. Taiwan: Industrial Development and Affairs Bureau, 1996.

[3] Worrell E, Meuleman B, Bloch K. Energy saving by efficient application of fertilizer. Resour Conserv Recycl 1995;13:233-50.

[4] Jakobsen ST. Aerobic decomposition of organic wastes 2. Value of compost as a fertilizer. Resour Conserv Recycl 1995;13:57-71.

[5] Robert RS, Rohlf FJ. Introduction to Biostatistics, 2nd ed. New York: W.H. Freeman, 1987.

[6] Environmental Protection Administration. Standard Methods, Taipei, Taiwan, 1996.

[7] Wu JS. Study on the influence of organic fertilizer on the Euphobia pucherrima growth rate. National I-Lan Institute of Agriculture and Technology Reports, 1996. 